\title{
BESCHRIJVING EENER REIS VAN BENGKALIS LANGS DE ROKAN-RIVIER NAAR RANTAU BINOEWANG.
}

DOOR

J. A. VAN RHN VAN ALKEMADE.

Maandag den 6den Augustus verliet ik Bengkalis met de kruisboot; ofschoon de wind in dezen tijd van het jaar meestal gunstig is en. wij ons ook thans mochten verheugen in een stevigen bries, vorderden wij echter slechts langzaam, daar het water oploopend en de stroom dus tegen was. Wij hielden den wal van het eiland Bengkalis en zagen aan den overkant, op Sumatra's vasten wal gelegen, de kampong Boekit Batoe, 'de verblijfplaats van den Datoe Laksamana, die door den Sultan van Siak als hoofd over Boekit Batoe is aangesteld. De kampong zelve bestaat uit een honderdtal huizen, op palen gebouwd en de bewoners houden zich bezig met de vischvangst, waartoe de Brouwerstraat zoo veel gelegenheid aanbiedt. Om één uur - wij waren om 8 uur des morgens vertrokken - waren wij op de hoogte van Tandjong Djati, de N. W. punt van het eiland Bengkalis en de schrik voor stoomschepen, die 's nachts van dezen kant de Brouwerstraat binnenkomen, aangezien hier geen licht is en eene nabij den Tandjong gelegen bank de vaart bij donker weder gevaarlijk maakt. Door de plaatsing van een licht aan Tandjong Djati zou aan zeevarenden een groote dienst worden bewezen. Van Tandjong Djati hielden wij koers naar Tandjong of Oedjoeng Leban, waar een modderbank is gelegen, zoodat men niet te dicht langs den vasten wal varen kan. Van Oedjoeng Leban loopt tot Boekit Batoe de pantei Merombong, waarlangs men tot laatstgennoemde kampong loopen kan. Weldra kwamen wij nu in de Selat Domei of Roepat, eene vroegere verblijfplaats van de vele zeeroovers, die dit ge-

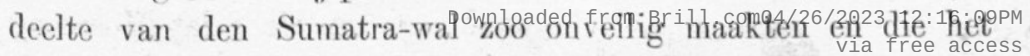


eiland Roepat, ook wel Segaro genoemd, van den vasten wal scheidt. Des avonds ten 7 ure gingen wij ten anker; de wind was gaan liggen en door den sterken stroom dreven wij meer af dan dat wij vooruitgingen. Niet ver van Tandjong Tegoe besloten wij dus dien nacht te blijven liggen, tenzij een goede wind des nachts het voordeelig mocht maken om verder te zeilen, hetgeen niet waarschijnlijk was. Den volgenden morgen om 5 ure gingen wij verder. Links hadden wij het gebied van den panghoeloe van Domei, die, aangesteld door den Datoe Laksamana van Boekit Batoe, hier het bestuur uitoefent. Hij heeft echter weinig te zeggen en moet bijna alle gezag afstaan aan zekeren Intji Oedah, een neef van den Datoe Laksamana. Eenigszins gewichtige zaken worden door den Datoe Laksamana zelven berecht en strekt de rechtsbevoegdheid van den panghoeloe zich slechts uit tot het opleggen van boeten, een bedrag van 40 realen $(1$ reaal $=f 0.60)$ niet te boven gaande en van welke uitspraak dan nog appel kan worden aangeteekend.

De bevolking in Domei vindt haar bestaan in den landbouw en de vischvangst en houdt zich meestal in hare ladang (droog rijstveld) op; de eenige kampong heet Poea of Bindjei, nabij de Soengei Domei gelegen en de woonplaats van den panghoeloe. Aan den rechterkant hadden wij het eiland Roepat, dat een ronde gedaante heeft en door de Selat Moeroeng van het eiland Medang is gescheiden. Het eiland is weinig bewoond; aan de Selat Domei houden zich eenige maleiers van den overwal op, die tijdelijk hier hun verblijf opslaan om in hunne kelong (soort van fuik) visch te vangen, die, gezouten en gedroogd, naar Singapore en Malakka wordt uitgevoerd. Sommigen leggen hier ook ladangs aan, doch de aanwezigheid van talrijke wilde varkens doet den rijstbouw veel overlast aan. De maleiers, waarvan hier sprake, staan onder het gezag van den panghoeloe van Domei, die hier echter geen afzonderlijken vertegenwoordiger heeft. Aan de Selat Moeroeng wonen Orang Sakei, hier meer bepaaldelijk Orang Akit genaamd. Zij behooren tot een volksstam, dieoorspronkelijk op het maleische schiereiland thuis behoort en die, van daar overgestoken naar Sumatra's vasten wal, thans nog in de boven-Mandau (Siak) haar verblijf houdt. Het zijn menschen, die hoofdzakelijk leven van hetgeen de bosschen hen opleveren en zij houden zich in de bosschen op; hun getal wordt geschat

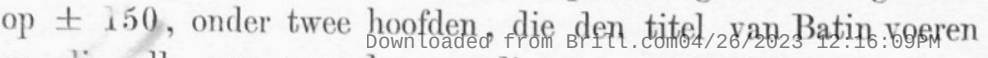
en die elk aan een der mondingen van de Sèlatrellbereseng 
verblijf houden. Van lieverlede hebben zich aan de Selat Moeroeng ook Chineezen neergezet, die zich daar bezighonden met de vischvangst en het zagen van balken wit de zoo deugdzaam hout opleverende Bintangoer. Zij huwen met vrouwen, tot de Orang Akit behoorende, met welken volksstam zij zich om zoo te zeggen langzamerhand vermengen. Ook de bereiding van belatjan (trassi) uit gedroogde garmalen levert lim een bestaan op. Behalve een aantal goede houtsoorteu, waaronder Medang, Merantei en Bintangoer de voomamsten, levert het eiland niet veel bijzonders op; eigenlijke rivieren zijn er niet, doch talrijke meer of min bevaarbare soengei's vinden hun uitwatering in de straat. Drinkwater verkrijgt men uit wellen, die nabij elke woning zijn gegraven. Aan weerskanten van de straat ontmoet het oog een dicht bosch, dat aan de oevers voormamelijk uit Bakau en Kayoe Tengah, beiden wortelboomen, bestaat.

De Selat Roepat levert een uitstekend vaarwater; men zij alleen voorzichtig niet te dicht langs den kant te gaan, vooral bij de eilanden, die dikwerf door een bank zijn omgeven. Verder zeilende passeerden wij Tandjong Kapal, zoo genoemd, omdat hier indertijd een schip strandde, en daarna de eilandjes Menteleh, Rampang, Payoeng, Mampoe en Ketam. Tusschen Poelau Payoeng en P. Ketam ligt nog het eilandje Atoeng. Geen dezer eilanden is bewoond; toch worden sommigen van tijd tot tijd bezocht door lieden van den overwal, die Semamboe (rotan) komen inzamelen of wel was uit de Sialangs (boomen waar zich bijen nestelen) weuschen te halen. Ook lokan (d. z. mosselen) treft men op de eilandjes aan en op Poelau Ketam, gelijk de naam reeds aanduidt een soort van krabben. Toen wij op de hoogte van Tandjong Bakal toewa aan den Sumatra-wal gelegen en waar een bank gelegen is, die bij laag water slechts \pm 3 voet water heeft, waren gekomen, was het reeds duister en hielden wij van den wal af. Verstandiger ware het geweest hier te ankeren, daar het vaarwater naar de Rokan-rivier onbekend is en het hier wemelt van grootere en kleinere zandbanken. Ook wij zouden dit ondervinden, toen wij des nachts om een uur op een bank stootten, terwijl de duisternis ons geen land deed ontwaren en wij dus bij geen mogelijkheid konden weten waar wij waren. Waarschijnlijk waren wij door den stroom uit den wal gedreven; hoe het zij, wij waren in eene zeer hachelijke

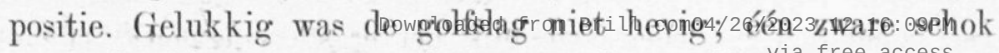
en de kruisboot ware te pletteren geslagen. Na via free access 
rakten wij tegen half drie weder in diep water, doch hadden geen kwartier gezeild of wij bonsden weder op een zandbank, tot ons aller groote ontsteltenis. In angst wachtten wij het daglicht af, dat ons ten minste wellicht in de gelegenheid zou stellen om waar te nemen, op welk punt wij ons bevonden. Ook deze hoop werd ons ontnomen; toen het licht geworden was, zagen wij slechts in de verte een dikken nevel, die ons vermoeden deed dat dáár land was; zeker wisten wij het echter niet. Tot onze groote vreugde geraakten wij tegen 6 ure weder in diep water en zeilden op goed geluk verder, steeds $12-16$ vadem water peilende. Om negen uur werd het land duidelijker zichtbaar en besloten we zoo dicht mogelijk te naderen om te zien op welke hoogte wij waren.

Om twee uur herkenden wij door het hoog geboomte, dat daar groeit, de Telok Dalam en bleek het nu, dat wij ten N.W. van het eiland Roepat gestooten waren op zandbanken, bekend onder den naam van Beting Moemboel. Voor Tandjong Seneboei, die wij nu ook in het gezicht hadden, ligt een uitgestrekte modderbank, welke echter niet zoo gevaarlijk is, daar men op den modder stootende geen letsel aan het schip bekomen kan. Wij hielden dus zoo ver mogelijk uit den wal, ofschoon ons later is gebleken, dat het beste vaarwater, dat wij hadden kunnen nemen, was geweest langs den wal van af Tandjong Seneboei naar Tandjong Radja berdjamoe (zoogenaamd omdat in vroeger tijd de sultan van Siak hier de vorsten der onderhoorigheden onthaalde) en zoo langs Tandjong Saroesamati, in welk vaarwater bij laag tij, aan den ingang één en verder twee vadem water staat. De gouvernementsstoomer Koetei maakte eens van dezen weg gebruik. Ofschoon zeer ver uit den wal, geraakten wij toch tegen 4 ure in den namiddag vast, doch daar het laag water was, rekenden wij, thans op de hoogte van Tandjong Radja berdịamoe zijnde, met den vloed, de monding der Rokan-rivier te kunnen binnengaan. Dit gebeurde ook, echter niet dan nadat wij nog eenige angstige oogenblikken hadden doorgestaan. Het was windstilte, doch eensklaps begon het zoo hard te waaien dat het weinig had gescheeld of de kruisboot was omgeslagen. Tot ons voordeel waren de zeilen in tijds gereefd; ware dit niet het geval geweest, voorzeker ware de kruisboot omvergewaid. Toch vatte het hooge wand nog zoo-

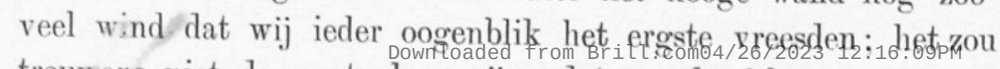

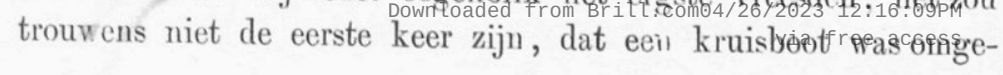


slagen. Deze vaartuigen hebben over het algemeen een te hoog want en reeds bij matigen wind moet het topzeil worden gereefl. Door den regen begon de wind te liggen; het water begon inmiddels te stijgen en kwamen wij des avonds te 7 ure met oploopend water de Rokan-rivier bimen. Weinig tijds daarna lieten wij het anker te Bagan Api-Api vallen. Het was geen aangename reis geweest; zij leerde ons hoe voorzichtig men in dit onbekend vaarwater moet zijn, dat zonder een goeden lools niet te bevaren is, of men moet de route nemen, zeer ver buiten het eiland Roepat en de nabij Tandjong Seneboei gelegen modderbank om.

De monding der Rokan-rivier is zeer breed; de rivier zoude een uitstekenden handelsweg opleveren, zoo niet hare bevaarbaarheid door de vele banken en door de later te behaudelen vloedgolf (bena) gevaarlijk voor de scheepvaart was. Het water dringt eerst, opgestuwd door de voor de monding der rivier gelegen modderbank bimen, met eene kracht, die een hevigen stroom en op sommige plaatsen de vloedgolf (bena) doet ontstaan.

In de monding der rivier bevinden zich twee eilandjes Poelau Lalang besar en P. Lalang ketjil, waarvan het laatste voor de monding der Koeboe-rivier gelegen is. De legende omtrent het ontstaan dier eilandjes vinde hier eene plaats.

Weleer woonden aan de monding der Rokan-rivier een man en eene vrouw, die in zeer behoeftige omstandigheden verkeerden en leefden van aalmoezen, hen door voorbijgangers geschonken. Zij hadden een zoon Lalang genaamd, die zich in de wijde wereld begaf om handel te drijven. Na vele rijkdommen te hebben verworven huwde hij eene vrouw uit den gegoeden stand, waarna hij besloot, naar zijne vroegere woonplaats terug te keeren. Hij ankerde met een groote en een kleine prauw aan de monding der Rokan-rivier, waar hij zijne ouders nog aantrof, doch die hij niet wilde erkennen, omdat hij voor zijne vrouw met zijne geringe afkomst verlegen was.

$\mathrm{Na}$ alle moeite te hebben gedaan om hun zoon te bewegen hen als zijne ouders te erkennen, verlieten de vader en moeder de prauw, waarop hun zoon, vergezeld van talrijke volgelingen, verblijf hield. Korten tijd daarna zonk dat vaartuig evenals de kleinere sampan die met een touw aan de grootere was vastgemaakt. De groote prauw werd het eiland Lalang besar, de kleine Ealang ketjil en het touw dat beide prauwen verbond, werd de bank, die thans nog tusschen de beideredladodesn 
wordt aangetroffen. De ouders van Lalang veranderden in twee boomen, die nog, de eene overhellende naar de land-, de andere naar de zeezijde worden getoond.

De eilanden Lalang besar en Lalang ketjil leveren niets op en ziju onbewoond; zij strekken slechts tot verblijf van wilde varkens en ettelijke kiekendieven (boeroeng lang).

Alvorens verder te gaan een enkel woord over de landschappen Bangka en Koeboe, die beide aan de monding der Rokan-rivier, het eerste links en gedeeltelijk rechts, het tweede rechts, gelegen zijn.

De grens tusschen Bangka en het gebied van den panghoeloe van Domei is de Soengei Seneboei; de waterscheiding der Bangka- en Koeboe-rivier, net Tandjong Pekaitan, aan de zeezijde, vormt de grens tusschen Bangka en Koeboe, terwijl als grens tusschen Bangka en Tanah-Poetih aan den linkerrivieroever Oedjoeng Mera en aan den rechter-rivieroever Tandjong Bakong wordt opgegeven.

Omtrent de vroegere geschiedenis van Bangka, en dit is ook van toepassing op Koeboe, is weinig of niets bekend. Alleen weet men dat nederzettingen uit Djohor het eerst beide landschappen hebben bevolkt en de tegenwoordige toestand wettigt het vermoeden, dat zij later onder den invloed van TanahPoetih zijn gekomen en hiermede tegelijk onderhoorigheden van Siak zijn geworden.

Bangka heeft eene bevolking van \pm 1000 zielen, die zich bezighoudt met den rijstbouw, de vischvangst en de inzameling van boschproducten. Zij is verdeeld in zes soekoes, nl. Toedjoeh Indoeh, Rebia, Mera pandita, Mera djamman, Aoe en Ramba. Aan het hoofd dier soekoes staan de Kapala soekoe, die humne aanstelling van den Sultan van Siak ontvangen en waaronder de Kapala soekoe Toedjoeh Indoeh, de voornaamste en tevens Datoe van Bangka is met den gelar (bij naam) van Indra Pahalawan en die als zoodanig den Sultan van Siak vertegenwoordigt. De andere Kapala soekoe zijn dan ook zijne helpers (tongkat's) en humne bevoegdheid in rechtzaken strekt zich slechts uit tot het opleggen van geldboeten groot 40 realen (d. i. $f 24$ ), terwijl de Datoe Indra Pahalawan tot 20 rijksdaalders beboeten mag.

Aangezien de kinderen, uit een huwelijk voortgesproten, de soekoe an de moeder volgen, spreekt het van zelf dat bovenbedoeide functies overgaan op den broeder of zגateres idadessen 
doch daar het huwelijk in zijne eigene soekoe niet verboden is, kan zich ook het geval voordoen dat de zoon den vader in zijne betrekking opvolgt. Men herkent hierin den menangkabauschen invloed, ofschoon de menangkabausche adat hier niet zuiver wordt toegepast.

De inkomsten der hoofden bestaan uit de geldboeten, terwijl zij het recht hebben om arbeid van hume anak-boewah, ter bebouwing van hunne ladangs te vorderen en de ingezamelde was voor halven marktprijs te koopen. De Datoe Indra Pahalawan krijgt bovendien jaarlijks 150 pd. st. als zijn aandeel in de verpachtingen. Over de onbillijke handelwijze van Siak om door verpachtingen vele inkomsten, die volgens de adat aan de hoofden des lands toekomen, zoowel in Bangka als in Koeboe en Tanah Poetilı aan zich te trekken, wijdden wij niet verder uit. Genoeg zij het hier aanteteekenen, dat het Siaksch bestuur hier allerverderfelijkst werkt en de vrije ontwikkeling der bovengenoemde landschappen niet weinig belemmert. Onze wensch is het dat het Gouvernement niet te lang drale met eene overname der rechten en dat door een billijk aandeel in de schadeloosstelling, de hoofden des lands zullen worden gedefroyeerd, waardoor tevens een einde zal worden gemaakt aan de vele klachten die zij thans - en ik voeg hierbij terecht — tegen het Siaksch bestuur hebben.

Eigenlijke kampongs vindt men in Bangka niet; alleen aan de Soengei Bentayer, waar ook de Datoe Indra Pahalawan verblijf houdt, treft men eenige huizen aan; overigens houdt de bevolking zich in hare ladang op of wel leidt zij een zwervend leven.

Op Bangka's grondgebied heeft men te Laboean Tangga, aan de Soengei van dien naam en ongeveer twee uren varen van Bagan Api-Api aan den linker-oever der Rokan-Rivier gelegen, eene vestiging van lieden uit Bangka. De vorige Datoe van Bangka, wiens zuster de schoonmoeder van het daar aanwezige hoold Orang kaya Djalîl was, schonk daar een stuk grond aan dezen weg om zich daar te vestigen, welke gift werd goedgekeurd door den Sultan van Siak, die Orang kaya Djalîl een schriftelijk bewijs van aanstelling tot hoofd gaf. De naam Laboean duidt reeds aan, dat hier een geschikte ankerplaats voor prauwen is, die echter nog beter doen van in de Soengei zelve te ankeren, aangezien daar de stroom minder snel is. De bevolking van Iaboean Tangga zal \pm 150 zielen bedragen, die 
een 60-tal huizen bewonen; zij zijn allen uit Koeboe afkomstig en houden zich voornamelijk bezig met vischvangst, handel en de teelt van vruchtboomen, die hier bizonder welig groeien. In kleine zaken spreekt Orang kaya Djalîl recht en wordt hij in let bestuur bijgestaan door zijn zwager Intje Abas en zijn jongeren broeder Ma Djewa. De soengei Laboean Tangga is wel bevaarbaar, doch loopt bij afloopend water bijna geheel droog.

Het landschap Koeboe strekt zich uit langs de Straat van Malakka. Hierboven vermeldde ik reeds als grens tusschen Koeboe en Bangka de waterscheiding tusschen de Koeboe- en Bangka-rivier, welke beiden hun oorsprong moeten hebben in de Laoet Lampangga, een moeras van groote uitgestrektheid. Die waterscheiding zou men ook als grens tusschen Koeboe en Tanah Poetih kumnen aannemen, aangezien een juiste grens niet bekend is, evenals tusschen Koeboe en Panei, welke volgens Koeboe, de Soengei Litoekang, volgens Panei de Telaga Tegenang zou zijn.

Door de laatst aldaar geheerscht hebbende cholera-epidemie is de bevolking van Koeboe zeer afgenomen; geheele huisgezinnen werden eene prooi dier ziekte, bekend onder den naam van penjakit tahoen, zoodat het aantal overgebleven zielen op niet meer dan $\pm 1200 \mathrm{kan}$ worden gesteld. Deze bevolking houdt zich grootendeels op in de benedenstreken, nabij de Koeboe-rivier; aan de overige soengei's die in straat Malakka uitmonden hebben zich, met uitzondering van de Soengei Dahoen Chinezen met der woon gevestigd, die zich bezighouden met het vangen en droogen van visch. De voornaamste van die Chineesche nederzettingen is aan de Soengei Panipahan.

De bevolking van Koeboe houdt zich bezig met het bebouwen van ladangs en de vischvangst, terwijl de inzameling van boschprodukten hen ook geen onbelangrijke winsten afwerpt. Zij is verdeeld in 4 soekoes, nl. Hamba radja, Rawa, Aroe en Bebas, aan welker hoofd een Datoe, aangesteld door den Sultan van Siak, is gesteld.

Oorspronkelijk was hier alleen de soekoe Hamba radja en is de soekoe Rawa, bestaande uit lieden, afkomstig uit Menangkabau, evenals de soekoe Aroe, wier leden van Poelau Kampei, bij Jangkat, afkomstig zijn, er later bijgekomen. De soekoe Bebas is nog al van lateren datum en bestaat uit lieden uit

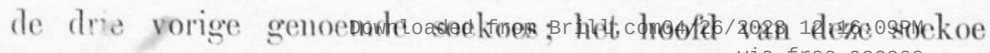
is een zoogenaamde dwarskijker (mata telinga) via free access 


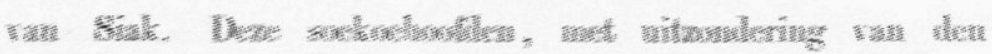

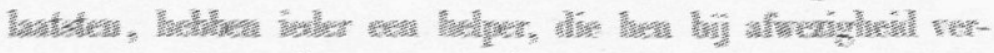

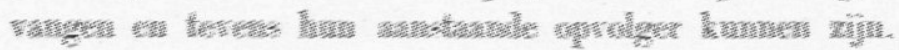

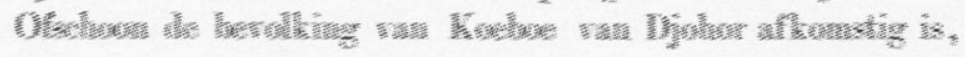

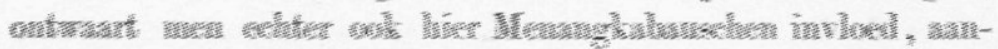

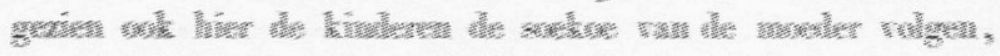

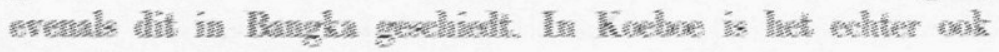

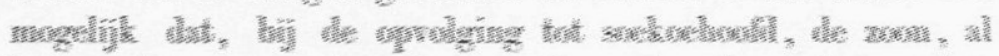

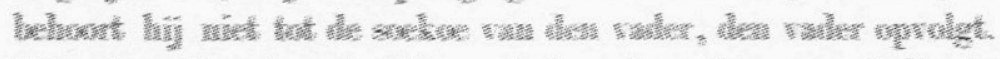

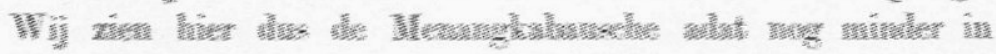

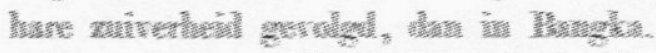

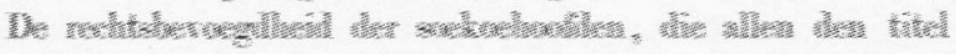

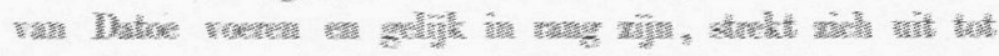

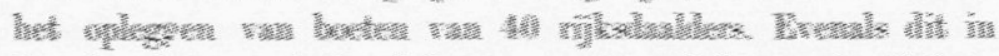

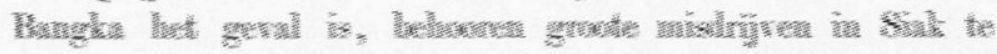

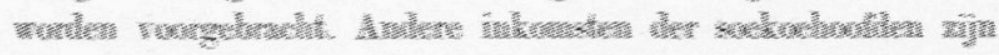
die, welke in reals hierroren als ook toekomende aan den Datoe van Bangka heb medegedeeld. Het hoofd der soekoe Hamba-radja wordt, hoewel hij geen bijzondere inkomsten geniet, toch als eerste onder de soekoehoofden beschouwd.

Tegenover den Sultan van Siak is de bevolking van Bangka en Koeboe verplicht om bij oproeping naar Siak op te komen hetzij hunne diensten bij eenen oorlog, hetzij voor het maken van bentings of wegen worden gevorderd, terwijl ook de Sultan het recht zou hebben om, indien hij het noodig had, van ieder huisgezin (klamin) vijf rijkssdaalders te heffen. De Sultan maakt echter van deze rechten geen gebruik, doch zij die door den Sultan met de inkomsten van Bangka en Koeboe zijn begiftigd, hebben zich door het verpachten van middelen ruim schadeloos gesteld.

Wij waren alzoo te Bagan Api-Api, zoo genaamd naar het vele brandhout 1 dat hier kan worden verkregen, geankerd en ik had den volgenden morgen gelegenheid die Chineesche nederzetting nader in oogenschouw te nemen en een en ander daaromtrent te vernemen.

Langs den rivier-oever strekt zich over eene lengte van \pm 2 palen de kampong uit, bestaande uit een aantal vrij bouwvallige woningen van ruw hout opgetrokken en met atap-omwanding Downtoaded from Brill.com๑4/26/2023 12:16: ๑9PM

via free access

1 Api-Api is de naam van een boomsoort. 
en dakbedekking. De bevolking, die zich met de vischvangst bezig houdt, is samengesteld uit een bende personen, die grootendeels niets te verliezen hebben, steeds bereid en in staat zijn elders een heenkomen te zoeken. Ver verwijderd van het Europeesch bestuur waant zij zich heer en meester van het land, waar zij zich heeft genesteld en gesterkt door een groot aantal geweren. Men zal misschien bezwaarlịk in Indië een woester maatschappij, geheel zonder vrouwen, vinden. Intusschen wordt hier veel geld verdiend, een gevolg van den buitengewonen rijkdom van visch en garnalen, die de monding der Rokan-rivier heeft.

Een vrij levendige, doch geheel ongecontroleerde handel met Singapoera en Pinang voorziet deze Chineesche kolonie van het noodige en worden de voortbrengselen van haren arbeid op die plaatsen te gelde gemaakt. Meestal treft men dan ook te Bagan Api-Api een viertal groote tongkangs aan en onderhoudt het 48-ton metende bootje van den pachter, een geregelde tiendaagsche gemeenschap met Singapoera. Het spreekt van zelf, dat men bij afwezigheid van de beschermende hand der wet, op andere wijze zijne partikuliere belangen verdedigde en gold dan ook aanvankelijk het vuistrecht; een latere oprichting van kongsies (vereeniging, vennootschap) beoogde de onderlinge bescherming van de leden en onderdrukking van hen, die geen lid waren. Eene kongsie, bestaande uit Hokkian-Chineezen, ontwikkelde zich het eerst en eene geregelde samenstelling, een algemeen hoofd, bijgestaan door mindere hoofden van verschillenden rang, zorgde voor de ten uitvoerlegging van bevelen, en een geregelde lynchwet velde hare vonnissen voornamelijk wegens vergrijping aan eens anders eigendom. 1

De grondslag tot de kampong werd gelegd door HokkianChineezen, die thans nog in het grootst aantal aanwezig zijn; zij die genoeg geld hebben verdiend keeren naar China terug, terwịl uit China nog steeds aanvoer van Chineezen plaats heeft. Het aantal der Hokkian-Chineezen bedraagt \pm 800 , dat der Tai Zjoe Chineezen \pm 90 , voor 't meerendeel in dienst van den pachter, terwijl er naar gissing een 30tal Haylam en een tiental Keh-Chineezen zijn, zoodat de totale nederzetting uit +1000 Chineezen bestaat.

Gelijk ik boven reeds mededeelde, is de voornaamste bron van

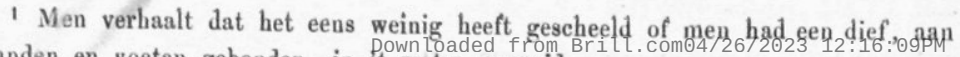
handen en voeten gebonden, in t $t$ water gegooid. 
inkomsten de bereiding van visch en garnalen. Gedurende de eene helft van het jaar is de visch-, gedurende de andere helft de garnalenvangst overvloedig, zoodat van de werkkrachten het geheele jaar gebruik kan worden gemaakt. De visch wordt gevangen in groote netten, die in de rivier worden opgesteld (djermal); bij hoogen waterstand haalt men de netten op en een nitvoer aan waarde van 1120,000 mex. doll 's jaars aan gedroogde visch duidt aan, dat de verkregen voorraad zeer belangrijk is. Garnalen vangt men bij laagtij en bedraagt de uitvoer eene waarde van $\pm 60,000 \mathrm{mex}$. doll., terwijl de afval, voor varkensvoeder gebruikt, een dollar per pikol opbrengt. De bereiding dezer artikelen is zeer eenvoudig; de visch wordt gezouten en daarna gedroogd, na eerst van ingewanden te zijn gezuiverd. De middelen te Bagan Api-Api zijn verpacht voor 1500 dollars 's jaars en heeft de pachter 't recht tot het uitsluiten van den verkoop van amfioen, sterke dranken, zout en touw van ramé, tot het geven van vergumning tot dobbelen en tot het heffen van een uitvoerrecht op garnalen bedragende voor kleine 40 en voor groote 50 dollarcenten, terwijl bovendien voor elke djermal 4. mex. doll. in de maand aan den pachter moet worden voldaan.

Tangkoe Nga, een zoon van Z. H. den Sultan van Siak, krijgt den pachtschat, aangezien hij door den Sultan met de inkomsten van Koeboe en Bangka, op welks gebied Bagar ApiApi is gelegen, is begiftigd.

Aangezien ik dienzelfden dag nog te Laboean Tangga wilde wezen, dreven wij des namiddags met den vloed daarheen, na met moeite een weg te hebben gevonden tusschen de vele djermal's (groote vischfuiken) die bij menigte in dit gedeelte van de Rokan-rivier door de Chineezen zijn opgesteld. Te Laboean Tangga, dat, gelijk ik boven reeds mededeelde, een goede ankerplaats is, bleven wij dien nacht liggen, daar het mijn voornemen was den volgenden morgen met den vloed naar Tanah Poetih te roeien. Het vaarwater tusschen Laboean Tangga en Tanah Poetih levert vele bezwaren op; naar boven gaande is de reis niet zoo gevaarlijk, daar men steeds hoog en oploopend water houdt; stroomafgaande blijft de reis steeds gevaarlijk en dient men een goeden loods te hebben om geen ongelukken te krijgen. De oorzaak van het gevaar ligt in de zandbanken, die zich in dit gedeelte van de rivier bevinden, en die bị laag water gedeeltelijk droog komen te liggen. Heeft men het ongeluk op

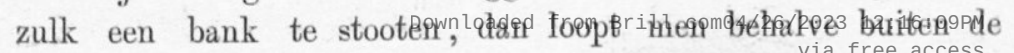


kans dat de prauw door den sterken stroom wordt omvergeslagen, buitendien het gevaar van door de bena (vloedgolf) to pletteren geslagen te worden, terwijl die banken daarenboven bestaan uit drijfzand, en het nog onlangs gebeurde dat een groote prauw in de bank wegzonk. Is er geen bena, dan heeft men ten minste de kans van bij oploopend water weer vlot te komen, doch blijft een prauw op de bank vastzitten in den tijd van de vloedgolf, dan is men onherroepelijk verloren, tenzij men zwemmende den wal kan bereiken. De bena heeft men op den tienden der maand (maanmaand), doch dan slechts weinig; zij neemt toe totdat zij op den $16^{\text {den }}$ het hevigst is om daarna weer af te nemen totdat zij op den 21 sten het minst is; op den $26^{\text {sten }}$ begint zij weder, is op den 1 sten der volgende maand het hevigst om den 6 den weder te verdwijnen. Wanneer men bedenkt hoevelen reeds het slachtoffer zijn geworden, dan is het niet te verwonderen dat men steeds bevreesd was voor deze reis en dat de Orang kaya Djalîl, die wellicht reeds honderde malen in zijn leven naar Tanah Poetih was gevaren, mị zeide dat hij op dit trajekt nooit gerust was, 't zij hij stroom op- of afwaarts voer.

Naar Tanah Poetih gaande, was het juist pasang-mati, zooals de inlander dit noemt, daar het de $6^{\text {de }}$ van de maand (Mohammedaansche) was. Toch was de stroom zeer sterk; daar, waar als het ware stroomsnelheid het hevigst was (de inlander noemt dit tali aroes), had men een zwaren golfslag of kabbeling in het water, even als op de zandbanken (betings) maar vooral op de bank bij de Soengei Bangka gelegen. Tk kom later op de bena terug, daar ik van Tanah-Poetih naar Laboen Tangga terugkeerende juist pasang besar (springtij) trof en toen uitstekend in de gelegenheid was dat indrukwekkend verschijnsel te zien. Door de goede hulp en kennis van het vaarwater van onzen loods (pandoe) kwamen wij behouden tegen 11 ure te Tanah-Poetih aan. Deze reis leverde niets bizonders op; alleen vernam ik dat Orang kaya Djalîl aan de Soengei Laboe, tegenover het eilandje Menasit, koflie had geplant, doch dat de uitslag verre van bevredigend was.

Tanah Poetih, welk landschap zijn naam ontleent aan den witten, zandsteenachtigen grond, dien men aantreft op de plaats, waar thans de kampong is, werd ongeveer eene eeuw geleden door Siak veroverd en daaraan onderhoorig. De bevolking is van djohorschen Downloaded from Brill, comp4/26.2023 12:16:09PM 
naar deze streken van na de uiteenspatting van het rijk van Djohor, waarmde bedoeld wordt het uitbreken der onlusten aldaar, waarin Radja ketjil, de eerste Sultan van Siak een voorname rol speelde. Radja Poerba was de grondlegger van het rijkje Lontar, het latere Tanah-Poetih evenals van Kapenoean, dat aan Lontar grenzende, voor de verovering van Tanah-Poetih door Siak, een broederstaat van Lontar was en thans ook nog aan Tanah-Poetih ten nawwste is verbonden. Men treft in de Rokan-streken meer van die broederstaatjes aan zoo als Temboesei en Ramba, welke beide van menangkabauschen oorsprong en Kotta Inten en Kotta Lama, die beide van djohorsche afkomst zijn. Niet machtig genoeg om zich alleen te handhaven tegenover Atjeh, dat tot in Tanah-Poetih zijne invallen deed, sloten zich Kapenoean en Tanah-Poetih aan bij de partij van Pageroeyoeng, die tot aan het Oosterstrand haren invloed deed gevoelen en kan hierin de mengeling van aristocratische (van Djohor) en democratische (van Pageroeyoeng) instellingen welke men in deze staatjes aantreft, hare verklaring vinden.

De grenzen van Tanah Poetih met Koeboe en Bangka gaf ik hierboven reeds aan; met Kotta Inten, ook Koenta genaamd, zou de Rantau Bais, aan den linkeroever der Rokan-rivier gelegen, de grens zijn en met Kapenoean de ayer-Meminda, die een rechter zijtak van de Rokan-rivier is. Een nauwkeuriger grensbepaling kan men niet van de hoofden te weten komeu, hetgeen in het verschiet tot moeilijkheden met de omliggende streken zal aanleiding geven. De bevolking houdt zich in hare ladangs op; de zetel van het inlandsch bestuur is te TanahPoetih, de eenigste kampong, welke men in het land aantreft. De inwoners van de vroeger bestaande kampong Bangka, die allen lieden van Bangka afkomslig waren zijn sedert verhuisd naar hun eigen land.

In rijstbouw, vischvangst, handel, de verzameling van boschprodukten, de teelt van gambir en het vervaardigen van gendies vindt de bevolking haar bestaan; vele gambir-tuinen zijn door een uitgestrekten boschbrand, die van Kapenoean tot voorbij Tanah-Poetih in het vorig jaar woedde, verwoest, doch zijn sedert weder nieuwe tuinen aangelegd. Het bevolkingscijfer kan men op \pm 700 stellen, waarvan \pm 150 in de kampong TanahPuetih een 60-tal huizen bewonen. De kampong ziet er zeer vervallen uit; eenige Chineezen hebben zich dasarogevestigghen 
koopen de boschprodukten op, doch hebben veel te lijden van de van diefstal niet af keerige bevolking, die aan dobbelspel en amfioen verslaafd, een treurig beeld levert van den toestand, waarin een volk door wanbestuur wordt gebracht.

De inkomsten van Tanah Poetih zijn door den Sultan van Siak geschonken aan den Mangkoe boemi of rijksbestierder, die de gezamenlijke middelen heeft verpacht voor 1250 en 200 pd. st. aan twee Chineezen. Van die inkomsten krijgen de Soekoehoofden $400 \mathrm{pd}$. st., zeker niet te veèl, wanneer men in aanmerking neemt dat hen eigenlijk het geheele bedrag toekomt. De grond in Tanah-Poetih moet voor landbouw geschikt zijn en zoude vooral het terrein bij Oedjoeng Mera zeer vruchtbaar zijn.

De bevolking is verdeeld in 4 soekoes, nl. Malayoe besar, Malayoe Tengah, Masa en Batoe Ampar, aan het hoofd waarvan de soekoe-hoofden door den Sultan van Siak zijn aangesteld. Aan het hoofd der handelaren staat een zekere Hadji Mohammed Taib die de tusschenpersoon is tusschen het inlandsch bestuur en de van elders komende handelaren. Het hoofd van de soekoe Malayoe besar is het voornaamste en ontvangt van de inkomsten $\frac{2}{5}$ gedeelte, terwijl de andere soekoe-hoofden $\frac{1}{5}$ ontvangen. Het hoofd der soekoe Malayoe besar heeft drie helpers (tongkat); dat van de soekoe Malayoe Tengah één en dat van de soekoe Batoe Ampar twee. Deze tongkats werden vroeger door de soekoe-hoofden, die den titel van Datoe hebben, aangesteld, doch thans door den Mangkoe boemi, hetgeen niet in overeenstemming met de adat is. Behalve het aandeel in die pachten, bestaan de inkomsten der soekoe-hoofden uit de opgelegde boeten, grondrente (tapak lawang) en een tiende der boschprodukten (pantjong alas); de opvolging heeft plaats op gelijke wijze als dit in Bangka geschiedt.

Door den invloed van den Tongkoe Mangkoe boemi en diens zoon Tongkoe Mansoer, die te Tanah-Poetih verblijf houdt, heeft eene verkrachting der rechten van de soekoehoofden plaats, die tot groote ontevredenheid leidt, aangezien zij volgens de adat de hoofden des lands zijn en slechts tegenover hun heer den Sultan van Siak verplicht zijn werkvolk te leveren benevens eene jaarlijksche persembahan (gift) in geld, rijst, kippen, enz.

De toestand in Tanah-Poetih is dan ook niet zooals die wezen moet, en alleen de plaatsing van een gonyernements: asph-

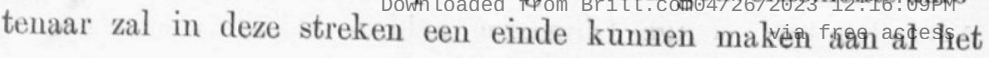


onrechtmatige, dat de welvaart van het land opoffert aan de bizondere belangen van de overheerschers.

Op den $10^{\text {den }}$ was ik te Tanah-Poetih aangekomen en vertrok van daar den $11^{\text {den }}$ Augustus des morgens. Na het door slechts enkele lieden bewoonde eilandje Laboean Papan te zijn gepasseerd als ook vele betings, die ook hier de vaart bij springtij zoo gevaarlijk maken, kwam ik om 11 ure bij Poelau Minjak en bleef ik des avonds in de telok Penjoengga ankeren, daar boomstammen en afdrijvend Bakong (een hooge grassoort) het varen des nachts niet wenschelijk maken. Den volgenden morgen kwamen wij om 12 uur te Negri Tinggi, waar een dertigtal huizen door lieden uit Rantau Binoewang werden bewoond. De verdere tocht naar Rantau Binoewang leverde niet veel merkwaardigs op; wij passeerden vele ladangs aan lieden uit Rantau Binoewang toebehoorende en de opkomende maan vergunde dat wij ook 's nachts door konden roeien. In de rivier was een hevige stroom, ofschoon die bij veel regen in de bovenlanden nog sneller is; weinig belangrijke Soengei's vinden in de Rokan-rivier hare uitwatering, waaronder de Batang Koemo de voornaamste is, buiten de Rokan-Kiri die zich bij Sako met de Rokan-Kanan vereenigt. Den geheelen weg langs zagen wij de sporen van den vreeselijken brand, waarvan ik hiervoren reeds gewaagde en was het dichte bosch herschapen in een ontbladerd aantal stammen. Waar de rivier zich kronkelde, had zich aan de tandjong (hoek) een zandplaat ${ }^{1}$ gevormd en voorbij de samenstrooming der Rokan-Kiri en Kanan waren vele boomen in de rivier aanwezig. Men deelde mij mede dat in het vorig jaar een stoombarkas tot Rantau Binoewang was opgevaren, doch ik vermoed dat die vaart ten gevolge van de vele boomstammen en sterke stroom in de rivier is gestaakt. Ik durf dan ook de vaart voor een stoombarkas verder dan Negri Tinggi niet aanbevelen, waarheen dan ook trouwens gemakkelijk per sampan de produkten, v.n.l. rotan, getah en was uit de bovenstreken kunnen worden aangevoerd. Op vele plaatsen in den rivierloop treft men z.g.n. danau aan, dat is de vroegere loop van de rivier en wees men mij nog een paar plaatsen aan, waar binnen korten tijd de rivier wel haar loop zou verplaatsen.

1 Daarom spreekt men in deze streek ook bij het bejaleu van het aantal

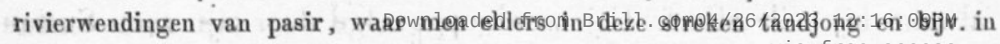
Palembang rantan gebruikt. 
Een ladang, door Boeginezen bewoond, herinnerde er aan, dat ook vroeger Boeginezen zich in deze streken hebben nedergezet; zij zijn echter schier uitgestorven en men toonde mij te Tanah-Poetih de reeds geheel vervallen woning van den laatst daar overgebleven en sedert overleden Boeginees, die de Soelewatang werd genoemd.

Nabij Rantau Binoewang waren eenige kampongs, hoogstens uit tien huizen bestaande, langs den rivieroever gebouwd en werd daar overal, evenals dit ook op de ladang het geval was, suikerriet geplant, waaruit men op een zeer primitieve wijze suiker bereidde. Overigens zag ik slechts djagong (turksche tarwe), oebi (namelijk de cassave waarvan tapioca gemaakt wordt) en sirih aangeplant, terwijl men zich ook hier en daar bezighield met het droogen van eene soort van visch, ikan gaboes, die in de Rokan-rivier wordt gevangen

Den $16^{\text {den }}$ Augustus, dus na vijf dagen reis kwam ik te Rantau Binoewang, de verblijfplaats van den Radja van Temboesei aan. De reis was voorspoedig geweest, waartoe de vele roeiers van mijne sampan het humme hadden bijgedragen; een inlandsehe prauw doet dikwerf meer dan 14 dagen over denzelfden afstand.

Alvorens thans verder te gaan, vereischt het eenige toelichting, hoe hier op Tanah Poetih's grondgebied sprake kan zijn van een staatje Rantau Binoewang, waarvan de vorst den titel van jang dipertoewan of radja van Temboesei draagt.

In Temboesei wilden de Padries, die zoo langen tijd den fakkel des opstands op de Weștkust zwaaiden, ook humne hervormingen in den godsdienst totstandbrengen en zekeren Pakir Saleh, later zoo berucht in de geschiedenis onder den naam van Toeankoe Temboesei, gelukte het den radja van Temboesei, destijds Sultan Achir Iamaän evenals de Radja's van Ramba en Kapenoean uit zijn land te verdrijven. Het is van algemeene bekendheid, dat Toeankoe Temboesei in 1838 door ons uit zijn versterkte kampong Daloe-Daloe, thans nog de hoofdplaats van Temboesei, werd verjaagd en uitweek naar Iinggi op de Westkust van Malakka. De vorsten van Ramba en Kapenoean keerden spoedig in hunue rijken terug, doch Sultan Achir Lamaän week uit naar Soengei Krangin Panei, waar hij overleed. Zijn zoon en opvolger Djamaloe l'alam vestigde zich aan de Soengei Dahoen, in Koeboe gelegen,

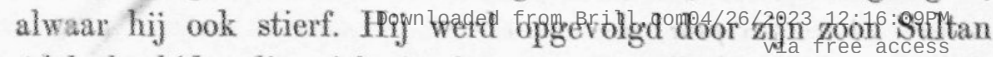
Abdoelwahid, die zich in het tegenwoordige Rantau Binoe- 
wang vestigde, Sultan Mohammad Dzen, de tegenwoordige Iang dipertoewan besar in Rantau Binoewang, is de zoon van den hierboven genoemden Sultan Abdoelwahid en heeft het woord Sakti aan den naam van zijn rijk, dat alzoo Rantau Binoewang Sakti heet, toegevoegd.

Het is hier niet de plaats om na te gaan in hoeverre deze nederzetting met of zonder vergumning plats vond, noch on de geschillen te bespreken welke sedert tusschen den Sultan van Siak en den Radja van Temboesei zijn gerezen; nog zij hier slechts vermeld dat de door Pakir Saleh verdreven Radja van Temboesei nimmer naar Temboesei is terugggekeerd en dat tegenwoordig daar het bestuur wordt gevoerd door een oom van den thans in Rantan Binoewang regeerenden Radja. Deze is de wakil (gemachtigde) van den Radja van Temboesei en dragt den titel van Tongkoe Maharadja. Wat de oorzaak is dat de vorsten van Temboesei nooit naar hun eigen land zijn teruggekeerd, laat zich voorshands hier niet beslissen, doch zeker wekt het onze bevreemding op. Rantau Binoewang is dus te beschouwen als te zijn voortgesproten uit het rijk van Temboesei en het verwondert ons niet dat de instellingen, die te Temboesei adat waren, ook hier worden aangetroffen; de landsinstellingen in Rantau Binoewang zijn derhalve een weerspiegeling van die van Temboesei en worden nog steeds gehandhaafd: Rantau Binoewang is een nieuw Temboesei à l'instar van laatstgenoemd rijk ingericht.

Uit het vorenstaande is gemakkelijk af te leiden dat Rantau Binoewang geen eigenlijke grenzen heeft, hetgeen echter niet wegneemt dat de vorst, die trouwens de geheele Rokan-streek als aan hem onderhoorig beschouwt, zich vestigt waar hij wil in dit onbewoond gebied en dat de bewoners ver verwijderd hun ladangs gaan aanleggen, terwijl elk der soekoes, waarin gelijk wij later zullen zien dat de bevolking wordt verdeeld, hare eigene gronden heeft. Dat hierbij wel eens meer als onderhoorig wordt beschouwd, dan wel rechtens te bewijzen is, ligt voor de hand, doch wij hebben ons daarmede hier niet in te laten.

Gelijk wij zagen, heeft de vorst den titel van Tan ; dipertoewan besar; op zevenjarigen leeftijd draagt de aanstaande vorst den titel van Tongkoe Moeda, op elfjarigen dien van Madjalelo en op vijftienjarigen leeftijd dien van Soetan Dzênal, welken titel hij behoudt totdat hij tot vorst is uitgeroepen. De bandahara (over wien later) en de andere orang besar besar (zie verder) roepen den vorst uit; het volk wordt dan in deiavedegableksal 
(balei) verzameld, waar de uitteroepen vorst op eene verhevenheid van gele stof is gezeten. De rijkssieraden zijn tegenwoordig, ten minste als de vorige vorst overleden is 1, en het hindoesch geschrift Sirih 2 wordt door een van de Imams voorgelezen. Daarna geeft de bandahara aan het volk (sakalian orang dan orangdagang di mana mana negri) kennis dat de Soetan Dzènal tot Tang depertoewan besar is verheven, waarop door het volk een driewerf "Daulat Toewankoe" (Heil! o vorst) doet hooren en een ieder zijn sembah voor den nieuwen vorst makt. Het spreekt van zelf dat bij zulk eene gebeurtenis de bevolking wordt onthaald.

De echtgenoote van den vorst wordt ook door den bandahara en de rijksgrooten gegelard (een bijnaam gegeven). Die van den vorigen vorst was Radja Siti, die van den tegenwoordigen radja Padoeka Siti, voor welke namen nog het woord Datoe wordt gevoegd. Die vrouw moet echter van vorstelijken bloede zijn.

Bij het overlijden van den vorst moet daarvan kennis worden gegeven aan de vorsten van Kapenoean, Rambaen Koenta; de bandahara zendt daartoe gezanten die tevens een stuk van het kleed Saoek (toedoeng) moeka genaamd waarin de doode begraven wordt, overbrengen. Zij worden vorstelijk en met kanongebulder ontvangen en zenden die vorsten karbouwen, rijst enz. als geschenken terug; de overleden vorst mag niet begraven worden alvorens zijn opvolger tot vorst is uitgeroepen.

De Radja wordt opgevolgd door zijn zoon; bij ontstentenis van dezen door zijn broeder. Zijn er geen nadere bloedverwanten, uit een vorstelijk huwelijk gesproten, dan kan de echtgenoot van 's vorsten zuster worden uitgeroepen en ook als deze er niet is een telg uit het Ramba'sche vorstenhuis, die dan door een algemeene vergadering der rijksgrooten en Soekoehoofden wordt gekozen.

Op den Iang depertoewan besar volgt in rang den Tang depertoewan of Iamtoewan moeda die zijn aanstelling van

1 De pas verkozen vorst werd uitgeroepen, twen zijn broeder, de regeerende vorst, afstand deed van deu troon en bleven toen de rijkssieraden achterwege.

2 Het gesehrift "Sirih" is een hindoesch stuk, waarin de vorst van Pageroeyoeng de geheele Rokanstreek zou wegschenken aan den oudsten voorvader van den Padja van Temboesei. Op dit stuk grondt de tegenwoordige Radja, onverklambaar genoeg, zijne aanspraken op de geheele Rokan-streek.

Eese Taroemba bevat de geschiedenis en wording van Temboesei; het is een

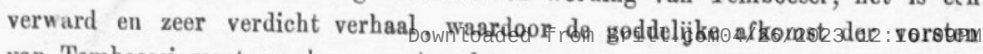
van Tamboesei moet worden aangetoond. 
den vorst ontvangt. Men zou hem onderkoning kunnen noemèn; na zijn zevende jaar krijgt de aanstaande Iamtoewan moeda den titel van Tongkoe Maharadja, dien hij later verwisselt met dien van Soetan Mantsoer. Tot deze waardigheid wordt veelal geroepen een kind uit het huwelijk van den vorst met eene vrouw uit de sembilan Soekoe voortgesproten, doch kan het ook zijn een kind van een oudere zuster van den vorst, hetgeen thans het geval is met de aanstaande Iamtoewan moeda.

De Iamtoewan moeda is een radja en wel in tegenoverstelling van de rijksgrooten (orang besar besar) waaronder de bandahara de eerste en voornaamste plaats bekleedt. De bandahara, die als Datoe wordt aangesproken, wordt door den vorst aangesteld en behoort of tot de soekoe Malayoe ò tot soekoe Ampoe, met dien verstande dat nooit tweemaal achtereen een bandahara uit dezelfde soekoe wordt benoemd. Behoort de bandahara, zooals de tegenwoordige tot de soekoe Malayoe, dan volgt diens neef (Kamanakan) en tevens helper (tongkat) den volgenden bandahara die uit de soekoe Ampoe wordt aangesteld en die nu den titel van Sri Padoeka Maharadja heeft op. Diens neef krijgt dan den titel van Pakoemoe Radja en de tongkat uit de soekoe Malayoe dien van Sri Padoeka Maharadja, welke laatste titel dus door den aanstaanden opvolger van den in functie zijnden bandahara wordt gedragen. Is derhalve de bandahara uit de soekoe Malayoe, dan is de Sri Padoeka Maharadja uit de soekoe Ampoe.

De bandahara is de handhaver van de aloude volksinstellingen; hij mag het land niet verlaten en is de gemachtigde van den vorst, als die afwezig is. Hij is belast met de bewaring der rijkssieraden, welke bestaan uit een gouden armring, een kris met gouden handvatsel en twee gongs, waarvan de kleinste bij het verscheiden van den vorst in de verte geluid zou veroorzaken en die bij groote droogte wordt gebaad. Bij plechtige gelegenheden worden zij te voorschijn gebracht, na te zijn afgehaald uit de woning van den bandahara met hetzelfde ceremonieel als waarmede een vorst ontvangen wordt. De bandahara is de raadsman van den vorst en vormt met de drie straks te noemen rijksgrooten, een rijksraad, die behalve de algemeene belangen des lands meer bizonder de belangen der Sembilan Soekoe behartigt. Die rijksraad is ook, zooals wij nader zullen zien, een

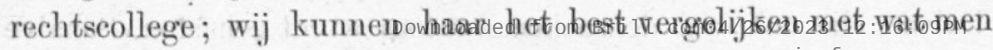
in andere streken de Karapatan noemt. 
Behalve de Datoe Bandahara zijn de orang besar orang Kaja Maharadja, Padoeka Sri Maharadja en Padoeka Madja lelo, die uit de Semboelan Soekoe door den vorst worden aangesteld. De vorst spreekt hen aan met Orang Kaya, de mindere man met Datoe. Hun waardigheid gaat over op zusterskind, hetgeen in verband staat met de menangkabausche adat, die, gelijk wij later zullen zien, hier vrij ongeschonden wordt gehandhaafd.

Ook de Soetan Mahmoed, die het hoofd is van de soekoe Dalam, behoort tot de orang besar besar. Hij wordt door den vorst aangesteld, die daartoe meestal kiest een kind uit zijn huwelijk met eene vrouw uit de soekoe Dalam voortgesproten. Bij de behandeling der soekoe Dalam komt die waardigheidsbekleeder nader ter sprake en zullen wij ook later zien welke rol hij speelt, wanneer de vorst gaat oorlog voeren. Ondei de mindere hoofden heeft men in de eerste plaats de Laksamana, die ook in oorlogstijd een voorname rol speelt. Met den Soetan Mahmoed treedt hij op als tusschenpersonen, wanneer de bandahara met zijn vorst verschilt van gevoelen en brengen zij dan het gesprokene aan beide partijen over. Inkomsten geniet hij niet; alleen krijgt hij zoo nn en dan een belooning van den vorst. Vreemd genoeg treft men in Rantau Binoewang ook een Sjahbandar aan; hij is het hoofd van de vreemde handelaren, wier zaken hij behartigt en zoo noodig voor den vorst brengt. Zijn betrekking is erfelijk in zijne soekoe, evenals dit met den laksamana het geval is.

Over de verschillende Bintara's en Panglima's, die in vredestijd als zwaarddragers, sirihdragers, oppassers, stuurlieden (djoeroe moedi) in dienst zijn volgt later nog het een en ander, daar zij ook in oorlogstijd eerst werkelijk in functie treden.

Zoo zijn wij dan eindelijk, na een rij van hoofden van meer of minder belang, gekomen tot de soekoehoofden, wier betrekking en standpunt zoo nauw met de belangen der bevolking zijn verbonden en als wier vertegenwoordigers bij den vorst wij reeds de bandahara en zijne drie mantris die als zoodanig ook wel de kapala sembilan soekoe worden geheeten, hebben leeren kennen.

De bevolking is verdeeld in tien soekoe's, nl. Malayoe, Ampoe, Bena, Koetie, Sabrang, Mai Poengkoet, Kandang Kapak, Mandeling, welke te samen ook de soekoe sariboe en de soekoe Dalam, die ook wel de soekoe seratoes wordt grehegten: Bebalve de soekoe Dalam, die zooals wij boven zagen, order feena $\$$ setan 
Mahmoed staat, hebben de soekoe's ieder hun eigen hoofd, de Kapala Soekoe, die door den Radja wordt aangesteld en wier betrekking erfelijk is, hun eigene soekoe, zoodat zusterskinderen (kamanakan) opvolgen. Elke soekoe is weder verdeeld in Indoehs, wier aantal verschillend is en aan 't hoofd waarvan Kapala Indoeh, met één de Kapala Indoeh poetjoek, als voornaamste. De gezamenlijke bevolking bedraagt \pm 3500 zielen, waaronder de soekoe Dalam begrepen is.

De grond om de kampong Rantau Binoewang tot zoover men de bedoeg (trom in de moskee) kan hooren, is het eigendom van den vorst en in gebruik bij de leden der soekoe Dalam, die hier hun ladangs aanleggen. De overige grond behoort aan de soekoes, die elk hun bepaald deel hebben dat door grenzen is bepaald. De Radja mag echter ook wel soekoegrond wegschenken en schijnt die verdeeling meer te zijn om twisten te voorkomen. De leden der verschillende soekoes leggen, altijd met vergunning van het betrokken hoofd, ladangs aan op welken soekoegrond zij verlangen, doch moeten steeds hun verplichtingen tegenover hun eigen Kapala Soekoe nakomen. Deze verplichtingen bestaan in het arbeiden gedurende vijf dagen in de ladang van het soekoehoofd als: één dag boschkappen, één dag boschbranden, één id. padi uitplanten, één id. padi oogsten en één id. padi ontbolsteren. Andere inkomsten van de soekoe hoofden bestaan in door hen opgelegde boeten.

Aan hun vorst is de bevolking verplicht pantjong alas of een tiende der verzamelde boschproducten en tapak lawang of van elke 100 hantangs padi tien 1, terwijl bovendien nog wel heerendiensten door den vorst worden genoten als dit noodig is.

De Soetan Mahmoed geniet als hoofd der soekoe Dalam dezelfde inkomsten als de andere soekoehoofden; de leden van zijne soekoe zijn diegenen, die elders tot de hamba radja worden gerekend te behooren. Kleine geschillen in de soekoe makt de Kapala Indoeh 2 uit; hooger beroep is dan bij den Kapala Soekoe of als er leden van verschillende soekoes in het geschil begrepen zijn, door hunne verzamelde soekoehoofden, wier bevoegdheid gaat tot het opleggen eener boete van 16 realen (d. i. $f 9.60$ ). Kunnen de soekoehoofdes eene zaak niet

1 Een gedeelte van de pantjong alas en de tapak lawang staat de vorst af aan den Bandahara en de drie andere Kapala Sembilan Soekoe.

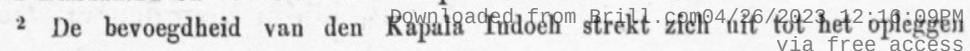
eener boete van 8 realen. 


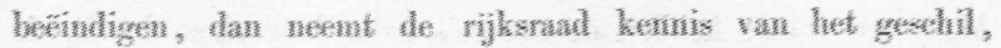

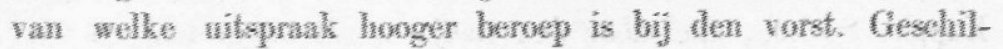

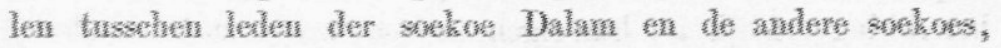
worten witgenualk door Soetan Mamovel en het betrokken soeknehoofl, van welke witsprak hooger beroen is biy den rijkswal, warin dan ouk Soetan Mahmoel zitting hest.

De Sjahbandar heeft exe bevoegdheid tot het opleggen van bocten 8 realen groot aan de handelaren warover hy gant. Grodtwe waken brugt liy woor den vorst, die darin zelf of als het crustige misdriven geldt - wn dit is lan altjo, ook met de 9 soekoe's het geval - in vereniging met zjue rijksgrooten nitsprank loet.

Hedf cen rediter cen vomis geveld, dat in hooger beroep wonlt verietigd, dan worlt degene die het vomis geshagen heeft, "t zij dit cen of meer personen is, gestraft met het geven wan wn lest en klederen (poetjock) aan dengene wiens zaak gevonnisd werd.

Er wordt recht gesproken volgens de adat en de sarat of mohammedaansche wet; de straffen bestaan steeds in geldbueten, terwijl in sommige gevallen de doodstraf wordt toegepast. Dit was althans vroeger zoo, en werd den misdadiger driemaal de slagader in de hals getroffen met een lans; bleef hij leven, dan werd hem de straf kwijtgescholden en het leven gelaten. Tegenwoordig zou dit niet meer gebeuren; de misdadiger zou slechts hebben te vluchten naar het huis van den Radja en hem zou verder geen leed geschieden.

Over den godsdienst der bevolking valt weinig meer te zeggen, dan dat zij is de mohammedaansche; zij volgt even als dit het geval is met de meeste volken op Sumatra, de leer van Sjafei. Het hoofd van den godsdienst is de Radja; voorts zijn er een achttal Imams, die optreden bij feesten en die de inzamelaars zijn van de djakat en pitra. Ook gedurende de vasten en bij mohammedaansche feestdagen hebben zij een rol, welke bestaat in het voorlezen uit den Koran en andere heilige boeken. Een viertal van de voornaamste Imams, vormen een zoogenaamden priesterraad die in geschillen betrefiende het huwelijk, erfrecht enz. recht spreekt. Minder in rang zijn de 9 Ketibs, die voorgangers zijn in de moskee, terwijl een zevental Bilals, als geestelijkeu vian den laagsten rang zijn aan te merken. Zij houden

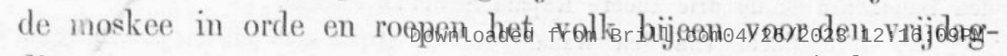
dienst. 
De bevolking volgt de voorschriften van den Islâm, wat betreft de vasten, het gebed 1 en de djakat nauwkeurig op; bij huwelijk en erfrecht volgt men de landsinstellingen, waarover een mohammedaansch vernis is gespreid. De djakat bedraagt 10 pCt. 2 van de opbrengst der produkten van het land en bij handelaren $2 \frac{1}{2}$ pCt. van de zuivere winst; zij wordt verdeeld onder de Imams, Ketibs, Bilals, terwijl ook een deel aan behoeftigen wordt gegeven.

De djakat pitra wordt verdeeld: $\frac{1}{3}$ voor den Radja, anakradja, enz.; $\frac{1}{3}$ voor de orang besar besar, de bintara's, de hoeloebalangs enz.; $\frac{1}{3}$ voor de Imams, Ketibs, Bilals en de panghoeloe missigit, die de moskee schoon houdt en op de bedoeg (trom) slaat om de gebedsuren aan te geven.

Alvorens de vorst zich ten strijde uitrust, onthaalt hij de bevolking, die tevens nieuwe kleederen ontvangt. Aan den Soetan Mahmoed en den Datoe Laksamana wordt opgedragen om het volk te verzamelen op eene vlakte, waar verschillende afdeelingen onder Panglima's worden opgesteld. Het aantal Panglima's is onbepaald; zij worden genomen uit de Sembilan Soekoe en uit de soekoe Dalam, in welk laatste geval het de Panglima 3 van de anak-radja is; zij zijn in 't rood gekleed en vooraan in 't gevecht, waarom dan ook de dapperste inlanders als Panglima worden verkozen.

De hoeloebalang bertoedjoe maken alles voor den krijg in orde en houden toezicht op de toebereidselen te velde; is dit afgeloopen, dan wordt hun werk nog eens nagegaan door de hoeloebalang bertiga. De hoeloebalang boewan blijven steeds in de nabijheid van den vorst en dragen bij feestelijke gelegenheden als de ontvangst van personen van rang, zwaarden, krissen en messen, evenals de hoeloebalang bertiga, terwijl dan de hoeloebalang bertoedjoe voorop loopen en een toembak bandarang dragen. Daarenboven moeten de hoeloebalang bertoedjoe bij het overlijden van den vorst 14 dagen de wacht bij het graf houden en tevens, met een toembok bandarang in de hand, aan het vooreinde der prauw, waarmede de vorst reist, de wacht houden. Het oorlogvoeren gaat zeer ongeregeld; de geweren zijn van

1 Te Bantan Binoewang waren langs den rivier-oever eenige stellages, waarop door Hadji's de dagelijksche gebeden werden verricht. Het aantal hadji's zoo mannelijke als vrouwelijke is te Bantan Binoewang zeer groot.

2 De minste hoeveelheid waarvan nog djakat wordt geheven is 690 gantangs engadi.

3 Deze is dan in het geel gekleed. 
slechte hoedanigheid en de kleine kanonnen (lila) die ten getale van \pm 50 aanwezig zijn, zijn verroest en gedeeltelijk versleten. In het schieten met geweren wordt de bevolking geoefend en waren aan den overkant van de rivier bij Rantau Binoewang een paar schijven geplaatst, die tot mikpunt dienden; somtijds hadden bij die schietoefeningen weddingschappen plaats en vermaakte men zich daarbij niet weinig.

De kampong Rantau Binoewang ${ }^{1}$ is de voornaamste van het land en de zetel van het rijksbestuur; de huizen, zoowel die van den vorst, de rijksgrooten als van den minderen man zijn uiterst bouwvallig en staat bij hoog water, als de rivier door vele regens gezwollen is, de kampong onder water, zoodat het niet te verwonderen is, dat men binnenkort zal gaan verhuizen en zich nederzetten te Negri Tinggi, waar de grond hooger gelegen is. Eenige klapper- en vruchtboomen, waaronder doerian, mangga en manggistan, treft men in de kampong aan, terwijl kippen en eenden in overvloed rondloopen. Een aantal prauwen, zoowel bovenlandsche als van beneden komende lagen voor de kampong, om weldra met boschprodukten volgeladen naar beneden te vertrekken. Des avonds namen verscheidene jongelieden deel aan het schieten op schijven, waarbij gewed werd en vermakten zich anderen met het schoppen van een van rotan gevlochten bal (sepak raga), waarbij het de kunst was om de bal niet den grond te doen raken. Bovenstrooms is een gedeelte van de rivier bestemd voor plaats, waar de vrouwen en ook de de Radja zich mogen baden en mag daar geen vaartuig passeeren of aan de vrouwen moet worden kennis gegeven dat men passeeren wil.

Vóór de geboorte van een kind hebben geen feestelijkheden plaats; alleen wanneer de aanstaande moeder ziek wordt, slacht men een geit en worden bekenden en vrienden onthaald. Na de geboorte, waarbij een doekoen hare hulp verleent, past deze nog 7 dagen het kind op en kan deze nog $\mathbf{4 0}$ dagen zoo noodig hare hulp verleenen. Na dien tijd krijgt de doekoen een geschenk in geld, waarvan de hoegrootheid afhangt van de welgesteldheid van den gever, benevens wat bras, 2 kippen, jonge klappers enz.

Meisjes worden besneden op haar 4e_-7e jaar; jongens op hun 15e jaar, op welken leeftijd zịj reeds behoorlijk eenige gedeelten uit den Koran kunnen opdreunen. 
Het huwelijk wordt gesloten met goedvinden van beide partijen, doch een man kan geen vrouw uit zijne eigene soekoe huwen en moet aan de betrokken soekoehoofden kennis van het aanstaand huwelijk worden gegeven. Na de verloving (toenangan) wordt de huwelijksgift, die minstens 4 realen bedraagt, aan de ouders van het meisje betaald en heeft korten tijd daarna de voltrekking van het huwelijk in de missigit en op een Vrijjdag plaats. Wanneer de Radja een vrouw uit de 9 soekoe huwt, moet hij 50 rijksdaalders huwelijksgift betalen en ontvangt hij zijne vrouw van den Datoe Bandahara. Een vorstentelg mag geen vrouw huwen uit de 9 soekoe, wel uit de soekoe Dalam.

Bij de voltrekking van het huwelijk wordt de vrouw vertegenwoordigd door haar vader, ouderen broer, jongeren broer of oom, terwijl, als geen nabestaanden wali kunnen zijn, de Radja als zoodanig optreedt. Na het huwelijk gaat de man inwonen bij de ouders van zijne vrouw.

Bij overlijden van den man volgen de kinderen de moeder, tot wier soekoe zij ook behooren; als de moeder sterft, volgen de kinderen de betrekkingen van de moeder. De harta poesaka komen bij overlijden aan de zusterskinderen (Kamanakan); de harta pentjarian deelt de man bij overlijden van zijne vrouw met zijne kinderen; sterft de man, dan erven de kinderen alles, ten minste wanneer het jongens zijn; zijn het meisjes, dan wordt de erfenis gedeeld met de zusterskinderen van den man. Wanneer er geen kinderen zijn, dan worden de harta pentjarian gelijkelijk verdeeld onder de nabestaanden van man en vrouw. Indien de overledene schuld nalaat, dan gaat die over, wat de man betreft op de zusterskinderen, wat de vrouw betreft op eigen kinderen.

Bij overlijden wordt het lijk gewasschen en daarna gewikkeld in een wit kleed, dat bij den vorst negen maal om het lijk wordt gevouwen. Aan het graf wordt een hoofdstuk uit den Koran of ander heilig boek voorgelezen en vereenigen daarna belangstellenden zich in het sterfhuis om feest te vieren, hetgeen wordt herhaald op den $3,7,40$ en $100^{\text {sten }}$ dag na het overlijden.

Slavernij treft men niet aan, doch pandelingschap, zoo nauw verbonden aan de rechtsbegrippen van een inlandschen staat, daarentegen veel. Indien iemand zijn schuld niet kan batalen, wordt hij pandeling van den schuldeischer, met wien hij dan een overeenkomst tot aflossing zijner schuld aangaat. 1 Vooreerst kan 
de pandeling in dienst bij zijn meester treden en vermindert dan de schuld met 10 pCt. 's jaars, terwijl hij wordt gevoed en gekleed. Ook kan de pandeling de ládang van zijn schuldeischer bewerken, en komt hem dan de halve oogst ten goede, terwijl zijn meester de andere helft tegen halven marktprijs overneemt en het bedrag tot aflossing der schuld doet strekken. Het doet zich ook wel voor dat de pandeling handel drijft en de helft van zijn winst tot aflossing zijner schuld betaalt.

Gelijk ik boven reeds met een enkel woord mededeelde, houdt de bevolking zich bezig met den landbouw, de verzameling van boschprodukten en den handel. Eenige artikelen zijn het eigendom van den vorst; zij zijn: ivoor, boeliga (bezoar), tjoela ', (schaamdeel van sommige dieren, in 't bizonder van den eekhoorn) moesang tjaboek ${ }^{2}$ (een witte civetkat) soemboe badak (de hoorn van een rhinoceros), moestika en maroepa (steensoorten); de aanbrenger ontvangt een geschenk in geld, somtijds ook een titel als: megat, mera en is vrijgesteld van verplichte diensten ten behoeve van den vorst.

De handel bepaalt zich tot Singapoera, werwaarts de ingezamelde boschproducten per prauw worden overgebracht en verhandeld. De invoer heeft plaats van Singapoera en brengt een prauw, die van Rantau Binoewang boschprodukten overbracht, een grooten voorraad van allerlei artikelen en snuisterijen terug.

Op veeteelt legt de bevolking zich niet toe; in het bosch moeten vele wilde karbouwen zijn en worden bij feestelijke gelegenheden eenige geschoten, ten minste als het aantal dat de vorst van verschillende kanten, als van den Bandahara, den Bandar enz. ontvangt, niet voldoende is.

De taal welke door de bevolking gesproken wordt is de maleische; dikwerf worden menangkabausche woorden gebruikt en ook de uitspraak der woorden (bijv. kampèh voor kampas, até voor atas) is veelal niet zuiver maleisch.

Den 16 den Augustus verliet ik Rantau Binoewang, een aangenamen indruk van vorst en volk medenemende. Daar wij den stroom mede hadden, reisden wij spoedig voort, zoodat wij in den namiddag reeds de Batang Koemoe passeerden, een rechter

1 Deze joela is zeldzaam en zoude de eigenschappen bezitten, die ook de bezoarstean zoo hooge waarde doen hebben.

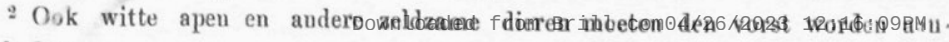
geboden. 
zijtak van de Rokan, aan welks bovenloop tin en steenkolen aanwezig moeten zijn.

In den nacht van 17 op 18 Augustus kwamen wij te Negri Tinggi; op de verdere reis moesten wij bij oploopend water, aangezien het roeien tegen stroom geen voordeel opleverde, stil blijven leggen om van het afloopend water dubbel te profiteeren. Bij grooten vloed gaat de stroom tot voorbij Kwala Sako, doch is dan niet sterk meer.

Des avonds van den $18^{\text {den }}$ ankerden wij in de Telok Tjoelas, nabij de Soengei van dien naam om daar de bena, die in dezen tijd op zijn hevigst was, af te wachten. Men ankerde hier veilig on ofschoon men op de dichtbij gelegen bank de bena duidelijk ziet en hoort, heeft men slechts een snellen stroom. Om niet te ver van Tanah Poetih te blijven liggen, roeiden wij des avonds met afloopend water naar de Telok Madar even voorbij het eiland Minjak. Toen den volgenden morgen om 8 uur de bena reeds in de verte zichtbaar was en zij zich langs den meer laaggelegen overkant van de rivier, als een hooge golf voortbruischte, hadden wij slechts een lichte deining (palembak), die geen letsel deed en Telok Madar dan ook als laatste station voor het ankeren van prauwen, die naar Tanah Poetih gaan, aanbeveelt. Zoodra wij met eenig voordeel tegen den stroom konden oproeien, vertrokken wij; een goede loods bracht ons door de gevaarlijke ondiepe passages, waarna wij om 2 uur te Tanah Poetih aankwamen.

Ik bleef daar overnachten om den volgenden morgen met afloopend water tot Laboean Tangga te roeien. Te Tanah Poetih kan men de bena reeds op grooten afstand zien aankomen, hetgeen een zeer indrukwekkend verschijnsel oplevert. In een oogwenk stijgt het water 3 voet; de prauwen moeten dan naar het midden van de rivier, waar wel een zware golfslag, doch geen branding is.

Nog voordat het water begon af te loopen, roeiden wij verder; voor dit gedeelte van de rivier moet men een uitstekenden loods hebben, die op de ondiepe plaatsen, steerls moet peilen hoeveel water er staat, omdat het stooten op een der banken, gelijk ik boven reeds mededeelde, groote ongelukken na zich kan sleepen. Daar de geul (aloer) zich op die ondiepe plaatsen dikwerf verplaatst en men nooit zeker kan zijn van

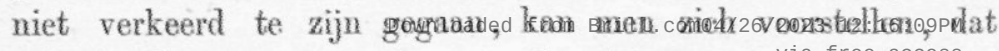
ook de bewoner van deze streek niet op zijn gemak is op 
dit gedeelte van de rivier, en dat hij meestal in de Soengei Bangka een volgende soeroet (afloopend water) afwacht, te meer daar hij in de Soengei Bangka niets van de bena heeft te lijden. Het vaartuig, waarmede ik reisde, schoot als voortgestuwd door den snellen stroom, in het water vooruit; na de bank bij Soengei Bangka, de gevaarlijkste van alle, te zijn gepasseerd kwamen wij in breeder en dieper vaarwater en lieten we, na bij het oversteken van de rivier van Telok Banò naar Soengei Bantayan door een hevigen wind te zijn overvallen, het anker vallen aan de monding der Soengei Jaboean Tangga, die reeds geheel droog geloopen was. Het was te gewaagd door te gaan naar Bagan Api-Api, daar wij den stroom zouden kunnen tegenkomen en aan ankeren of roeien dan toch geen denken was. Wij roeiden dan ook des avonds, toen het water weder begon af te loopen, naar Bagan Api-Api waar wij na 2 uren, dus des avonds om 10 uur aankwamen.

Tot den 27sten Augustus moest ik hier verblijven, verstoken van goed drinkwater en in een ondragelijken stank, door het droogen van visch teweeggebracht; aan den anderen kant was het weder eene vergoeding verlost te zijn van de vele muskieten en een soort van karbouwenvliegen, die het reizen op de rivier zoo onaangenaam maakten.

Op den $24^{\text {sten }}$ des avonds kwam het stoomscheepje van de pacht te Bagan aan; door de vele lading, die in sampans moest worden gelost, konden wij eerst den 27 sten des morgens om 6 ure vertrekken. Na een heel eind uit den wal te zijn gestoomd, hielden wij aan op Tandjong Seneboei en van daar op Tandjong Bakaltoewa waar wij den wal hielden en langs Tandjong Sentoeloe, Selat Domei binnen gingen om half zes des avonds. Des nachts om 4 uur staken wij over naar den wal van het eiland Bengkalis, waarvan wij om 8 uur des morgens de hoofdplaats bereikten. 